Editorial

\title{
Reproductive Health and Rights
}

\section{A R M Saifuddin Ekram}

In recent decades, most nations have come to recognize and accept the right of their citizens to reproductive health. Accordingly, they have signed treaties and accords, and endorsed the programmes of conferences on population and development. Naturally Bangladesh has not remained isolated from the developments on these issues,

Within the framework of WHO's definition of health as a state of complete physical, mental and social well-being, and not merely the absence of disease or infirmity, reproductive health addresses the reproductive processes, functions and system al all stages of life. Reproductiye health, therefore, implies that people are able to have a responsible, satisfying and safe sex life and that they have the capability to reproduce and the freedom to decide if, when and how often to do so. Implicit in this are: the right of men and women to be informed of and to bave access to safe, effective, affordable and acceptable methods of fertility regulation of their choice, and the right of access to appropriate health care services that will enable women to gc safely through pregnancy and childbirth and provide couples with the best chance of having a healthy infant. ${ }^{2}$

The common denominators of poor reproductive health are poverty and ignorance. Poor people who lack adequate food, basic health care, or modern contraception suffer grave consequences. The major categories of illness and mortality of poor women relating to reproductive health are: malnutrition and anaémia, common infectious diseases, complications of pregnancy, sexually transmitted diseases, HIV/AIDS, unsafe abortion and female genital mutilation. ${ }^{3}$

Bangladesh is one of the seven countries in the world where the number of men exceeds the number of women. According to various indicators the status of women in Bangladest is much lower than that of men. Traditional cultural and social values and practices have reinforced the lower status of women accorded to them in society and have limited their opportunities for education. technical and vocational training, employment and participation in the overall development process.

In Bangladesh, due to overall poverty health care receives inadequate resource allocations. At household level too, poverty results in limited expenditure on health care. Women are more disadvantaged than man in terms of access to health care and the quality of nutrition and health care received. A recent study has found that adult men make up the largest single group to be admitted in hospitals followed by boys. Only 14 percent of births are attended by trained personnel. According to the approach adopted by the health services women's health care is often restricted to their reproductive health and general health of women of all ages is neglected. ${ }^{4}$

But reproductive and sexual rights for the individual, whether man or woman, are foundation stones of prosperity and a better quality of life for all people. As such, they are absolutely essential to any hope of achieving sustainable development. Reproductive and sexual health is a right for both men and women-so agreed 180 nations at the International Conference on Population and 
Development (ICPD) in Cairo in 1994. The nations declared their goal to achieve universal access to reproductive health information and services by the year 2015 .

Yet millions still suffer from disease, injustice, injury. stunted lives. and even death when this right is denied. Most of these people are women, and most of these women are in the developing world.

The following statistical estimates show just some of the terrible effects of denying these human rights: 585.000 women - one in every minute-die each year from causes related to pregnancy. About 200,000 matemal deaths each year result from lack or failure of contraceptive services. 120-150 million women who want to limit or space their pregnancies are still without the means to do so effectively. At least 75 million pregnancies each year (out of a total of 175 million) are unwanted; they result in 45 million abortions and over 30 inillion live births. One million people die each year from reproductive tract infections. including sexually transmitted diseases (STDs) other than HIV/AIDS. There are an estimated 333 million new cases of STDs per year 3.1 million people in 1996 were infected by the human immunodeficiency virus (HIV) which leads to AIDS.120 million women have suffered female genital mutilation; another 2 million are at risk each year. The international community and individual governments have condemned the practice, yet it remains widespread in 28 countries. Rape and other forms of sexual violence are increasing. Contraception for women could be offered for just $\$ 1$ to $\$ 5$ per woman: safe childbirth could be guaranteed for $\$ 5$ to $\$ 10$. 'The total worldwide cost of better reproductive health care is roughly $\$ 17$ billion per annum-less than one week of the world's expenditure on armaments.

Since the Cairo and Beijing conferences' historic accords. countries have moved to put their recommendations into action. Numerous population and development policies have been revised. There have been legal reforms to butier protect women's rights and promote gender equality. Health services have been improved and reorganized.

The signers of the ICPD Programme of Action agreed that it is important for men to take more responsibility for their sexual and reproduetive behaviour and family life. Everyone is more aware than ever of the need to involve men in reproductive health programmes. Several NGOs are also conducting research tó determine what men's reproductive health needs are, and to better understand their sexual, marital, parenting, and family decision-making roles.

We must remember social, economic, and politicil rights are inseparable in practice. The sucial empowerment of women clearly contributes to. and depends on, good reproductive health. And this culi confer great benefits on the economic, political and social life of the community, and the future of the planet. ${ }^{1 / 2}$

\section{References}

1. The Right to Choose: Reproductive Rights and Reproductive Health. Interactive Population Center. http://www unipa org/intercenter/index.htm.

2. Global Policy Committee of the Worid Health Organization, 2 May 1994: and the WHO Position paper on health. Population and Development. Cairo 5-13 September 1994.

3. Women's Empowerment and Reproductive Health: Links throughout the Life Cycle. Inferactive Population Center. http:/l www. unipa.org/intercenter/ index.htm.

4. Consideration of Reports Submitted By States Parties Under article 18 Of The Convention On The Elimination of All Forms Of Discrimination Against Women Third And Fourth Periodic Reports of States Parties: (Bangladesh)Official Records of the General Assembly, Forty-second Session, Supplement No. 38 (A/42/38), paras. 503-572.

All correspondence to: A A M Sailuddin Ekram Associate Prolessor Department Of Medicine Raishahi Medical College Rájshaht. 